\title{
A Systematic Review of Substance Use (Disorder) in Individuals with Mild to Borderline Intellectual Disability
}

\author{
Neomi van Duijvenbode ${ }^{\mathrm{a}-\mathrm{c}}$ Joanne E.L. VanDerNagel ${ }^{\mathrm{a}-\mathrm{e}}$ \\ ${ }^{a}$ Tactus, Centre for Addiction and Intellectual Disability (CAID), Deventer, The Netherlands; ${ }^{b}$ Radboud University \\ Nijmegen, Behavioural Science Institute, Nijmegen, The Netherlands; ${ }^{C}$ Radboud University Nijmegen, Nijmegen \\ Institute for Scientist-Practitioners in Addiction, Nijmegen, The Netherlands; ${ }^{\mathrm{d}}$ Aveleijn, Borne, The Netherlands; \\ eUniversity of Twente, Faculty of Electrical Engineering, Mathematics, and Computer Science, Human Media \\ Interaction, Enschede, The Netherlands
}

\section{Keywords}

Intellectual disability · Substance use disorder · Prevalence · Assessment $\cdot$ Treatment

\section{Abstract}

Although the attention for substance use (SU) and SU disorders (SUD) among individuals with mild to borderline intellectual disability (MBID) has been growing exponentially, this form of dual diagnosis has largely been ignored by addiction medicine. In this article, we systematically review the research between January 2000 and June 2018 on the prevalence, assessment, and treatment of SU(D) among children, adolescents, and adults with MBID. A total of 138 articles were included. It is concluded that individuals with MBID are likely to be at a higher risk for developing SUD compared to those without MBID. Future research should focus on the detection of MBID among patients being treated in addiction medicine, the development and implementation of systematic assessment methods of SU(D) among individuals with MBID, and the development and evaluation of prevention and treatment interventions. System integration, interdisciplinary collaboration, and the development of tailored treat- ment for individuals with MBID are advised to improve treatment access and outcome for those who have developed SUD.

(C) 2019 The Author(s)

Published by S. Karger AG, Basel

\section{Introduction}

Substance use (SU) is highly prevalent in the adolescent and adult population. Although this is not necessarily problematic, a number of people develop a SU disorder (SUD). For instance, results from the 2016 National Survey on Drug Use and Health [1] indicate that 7.5 percent of the population aged 12 years and older had a SUD in the past year. More specifically, 5.6 percent of the people aged 12 years or older in the United States (approximately 15.1 million people) had an alcohol use disorder in 2016, and 2.7\% (approximately 7.4 million people) were classified with a drug use disorder. Similar findings have been reported by the World Health Organization in their World Mental Health Surveys among 26 countries [2], in which $2.6 \%$ of the 708,800 participants met the criteria for a drug use disorder. 
The risk of developing SUD after initial SU varies across persons. Indeed, a great deal of research has been directed at identifying risk factors associated with developing SUD. This research suggests that SUD is a multifaceted problem that can best be explained by a complex interplay between biological (e.g., genetics, physiological effects of substances), psychological (e.g., personality traits, comorbid psychiatric disorders), and social factors (e.g., socioeconomic status, peer pressure, SU by important others) [3]. All factors - biological, psychological, and social - interact with each other and can increase or decrease the risk for developing SUD in a given individual. Despite the complexity of this area, identifying common risk factors associated with the development and maintenance of SUD is essential to the improvement of prevention, early detection, and treatment. In addition, knowledge about SUD risk factors can also be used to direct scientific and clinical attention to high-risk groups that may need a specific or more intensified approach.

However, even though as early as 1932 East [4] wrote about alcoholism in "the feeble minded" as a specific population at risk for SUD, addiction medicine still pays little attention to whom we now call "individuals with mild to borderline intellectual disability" (MBID). An intellectual disability is characterized by deficits in intellectual and adaptive functioning that originates in the developmental period [5]. Intellectual functioning refers to a wide range of mental abilities (e.g., reasoning, planning, problem solving, judgment, and abstract thinking). It is measured by standardized IQ tests, and IQ scores between 50 and 85 are indicative of MBID. In the DSM-5, deficiencies in adaptive functioning, that is, skills that are needed to function in day-to-day life (e.g., conceptual, interpersonal communication, and practical skills), define whether a diagnosis of MBID is made.

In the past decade, it has become clear that individuals with MBID often experience more severe consequences of SU and are a risk group for developing SUD [6]. We will therefore systematically review and summarize the research on the prevalence, assessment, and treatment of SU(D) among individuals with ID. We will also propose a number of suggestions for policy and practice as well as several lines of research in this area.

\section{Methods}

A systematic review was conducted by identifying articles published from 2000 to June 2018 through an electronic search of Web of Science, PsycINFO, PubMed, and Eric. Searches were limited to published and peer reviewed full-text articles in English language

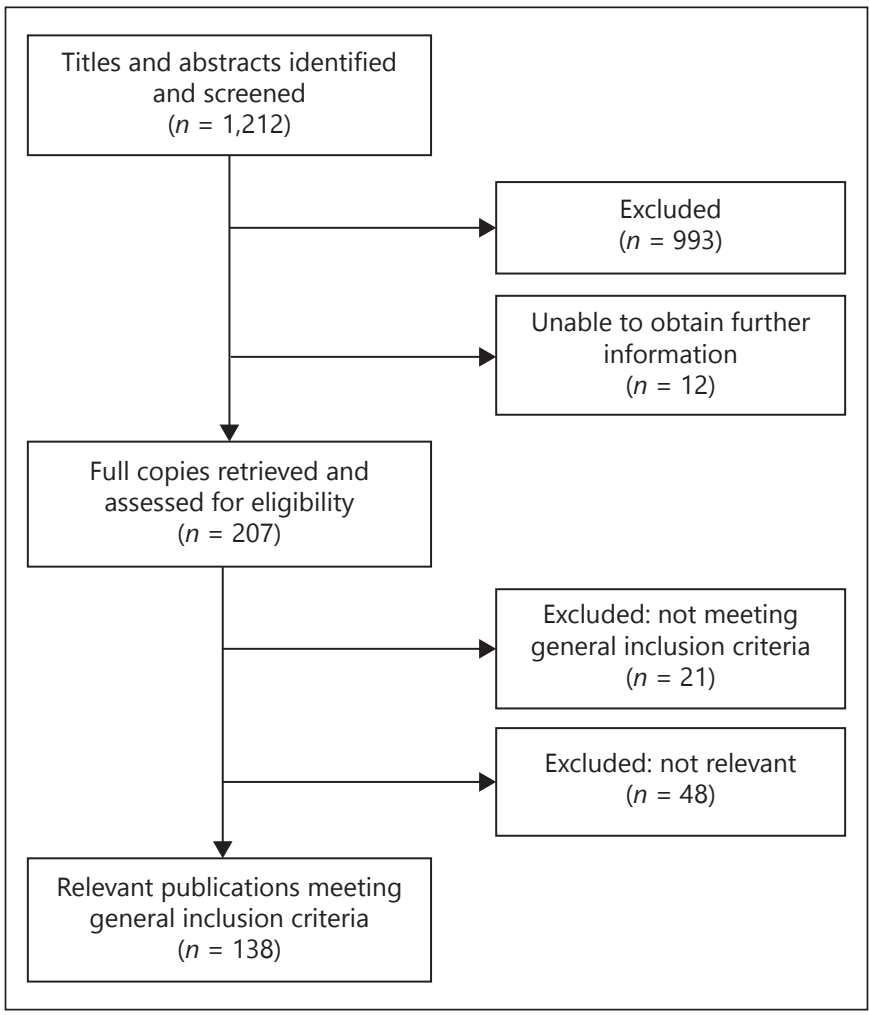

Fig. 1. Flow chart showing the selection procedure of articles for inclusion.

and with human subjects. Non-peer reviewed or unpublished research articles, conference proceedings, and abstracts were excluded. Search criteria included a combination of intellectual disability (learning disability, developmental disability, low IQ, borderline IQ, mental retardation, mental deficiency, intellectual developmental disorder) and SUD (addiction, tobacco/alcohol/drug/SU, tobacco/alcohol/drug/SUD, tobacco/alcohol/drug/substance disorder, tobacco/alcohol/drug/substance-related disorder, tobacco/ alcohol/drug/substance abuse, tobacco/alcohol/drug/substance misuse, tobacco/alcohol/drug/substance dependence, alcoholism, smoking) as keywords in the title and/or abstract. Articles with keywords regarding prescribed medication, (the effects of) prenatal exposure to substances and maternal SU were excluded.

The search yielded 1,212 unique articles. The first author prescreened titles and abstracts from all articles identified in this electronic search. Articles not meeting the inclusion criteria and articles from which we were unable to obtain further information to assess their relevance for the current study were excluded. No methodological quality criteria were used in the selection procedure. A total of 207 articles remained and were assessed for eligibility by both authors independently (Cohen's kappa $=0.82, p<0.001$, percentage of agreement $=92.2 \%$ ). Articles that did not meet the general inclusion criteria (i.e., non-peer reviewed articles, letters to the editor, editorials, conference proceedings, abstracts) or were clearly not relevant for the purpose of this article (i.e., did not cover SU[D] in individuals with MBID) were excluded, ultimately further reducing the number of relevant articles to 138 . The selection procedure is 


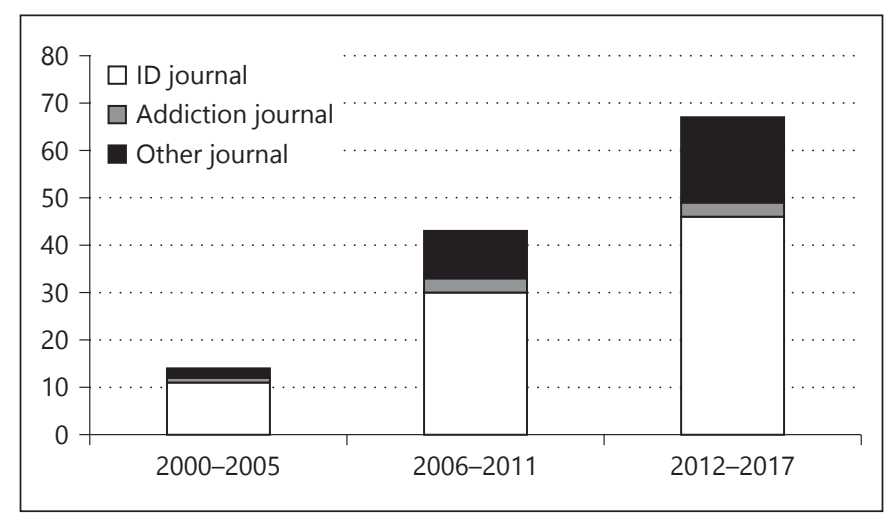

Fig. 2. The number of articles on SU(D) among individuals with MBID published in ID-journals, addiction journals and other journals between 2000 and 2017. ID-journals, intellectual disability journals; SU, substance use.

summarized in a flowchart (Fig. 1). A list of all the included articles is presented in online supplementary Appendix A (for all online suppl. material, see www.karger.com/doi/10.1159/000501679.

\section{Results}

\section{Origin of Articles}

Figure 2 summarizes the origin of the included articles published in 2000-2017. It shows that the scientific attention for SU(D) among individuals with MBID has been growing exponentially. The vast majority of the articles has been published in journals on intellectual disability $(69.6 \%, n=96)$. Only 8 articles $(5.8 \%)$ were published in journals on SUD (addiction journals) and 30 articles were published in "other" journals, for example, those focused on public health or psychiatry. A similar trend is witnessed for the first half of 2018, with 14 articles published articles on the subject. Only one of those was published in an addiction journal.

Of the 138 included articles, 18 were reviews of the literature (online suppl. Appendix A [1-18]) and 9 were descriptive or opinionated articles (online suppl. Appen$\operatorname{dix} A$ [19-27]). A total of 111 articles contained original data on prevalence and risk factors $(n=88)$, prevention $(n=2)$, screening and assessment $(n=7)$ and treatment $(n=19)$ of SUD in individuals with MBID. In addition, 10 articles contained original data on the neuropsychology of SUD in individuals with MBID (Fig. 2).

\section{Prevalence and Risk Factors}

The vast majority of articles on SUD among individuals with MBID has been directed at describing its preva- lence and risk factors (Table 1). Interestingly, only 3 of those have reported the prevalence of MBID in addiction medicine, indicating that around $30-40 \%$ of the patients in addiction medicine have MBID. All other articles report data on the prevalence of SU or SUD among individuals with MBID. These data are difficult to compare, due to differences in population (i.e., differing levels of intellectual disability, treatment settings, comorbid psychiatric disorders), definition and scope of SU (i.e., including or excluding tobacco use, differing definitions of SU, misuse, abuse, and SUD) and methodological and measurement issues $[6,7]$. Therefore, the reported prevalence rates often differed profusely across studies.

Among children and adolescents with MBID (aged 11-21 years), the lifetime prevalence rates ranged from 0.0 to $49.8 \%$ for tobacco use, $15.6-75.4 \%$ for alcohol use, and $2.4-13.0 \%$ for cannabis use. Use of other illicit drug was not reported for this age group. To compare, results from the 2016 National Survey on Drug Use and Health [1] indicate that $15.3 \%$ of the adolescents (aged 12-17) has ever used tobacco, $27.0 \%$ has ever used alcohol, and $14.8 \%$ has ever used cannabis. These data suggest a higher prevalence of tobacco and alcohol use and a lower prevalence of cannabis use among adolescents with MBID compared to adolescents without MBID. Similarly, the prevalence of SUD among adolescents with MBID (ranging $0.1-2.7 \%$ ) was lower compared to that of adolescents without MBID (5.2\%). Overall, given the relatively high rates of adolescents with MBID without any SU, levels of SUD in adolescents with MBID as a group are relatively small. In those who do use substances, however, there seems to be a higher risk for SUD than adolescents without MBID.

Across articles on adults with MBID (aged 18+ years), the lifetime prevalence rates differed even more. For example, the prevalence rates ranged from 6.0 to $98.4 \%$ for tobacco use, and $2.5-97.3 \%$ for alcohol use. Reported prevalence rates of cannabis use centered around $50 \%$ and those of stimulants use around $19.2 \%$. In comparison, $67.7 \%$ of the general adult population has ever used tobacco, $85.6 \%$ has ever used alcohol, $47.0 \%$ has ever used cannabis, and $6.8 \%$ has ever used stimulants [1]. This indicates that the prevalence of tobacco and alcohol use among adults with MBID is lower compared to the general population. The prevalence rates of cannabis and stimulants use, on the contrary, are similar and higher, respectively. Overall, the prevalence of SUD among adults with MBID (ranging 0.5$46.0 \%)$ seems lower compared to that of the general population $(7.8 \%)$. 
Table 1. Overview of articles on the prevalence and risk factors of SU and SUD in individuals with MBID, sorted by population

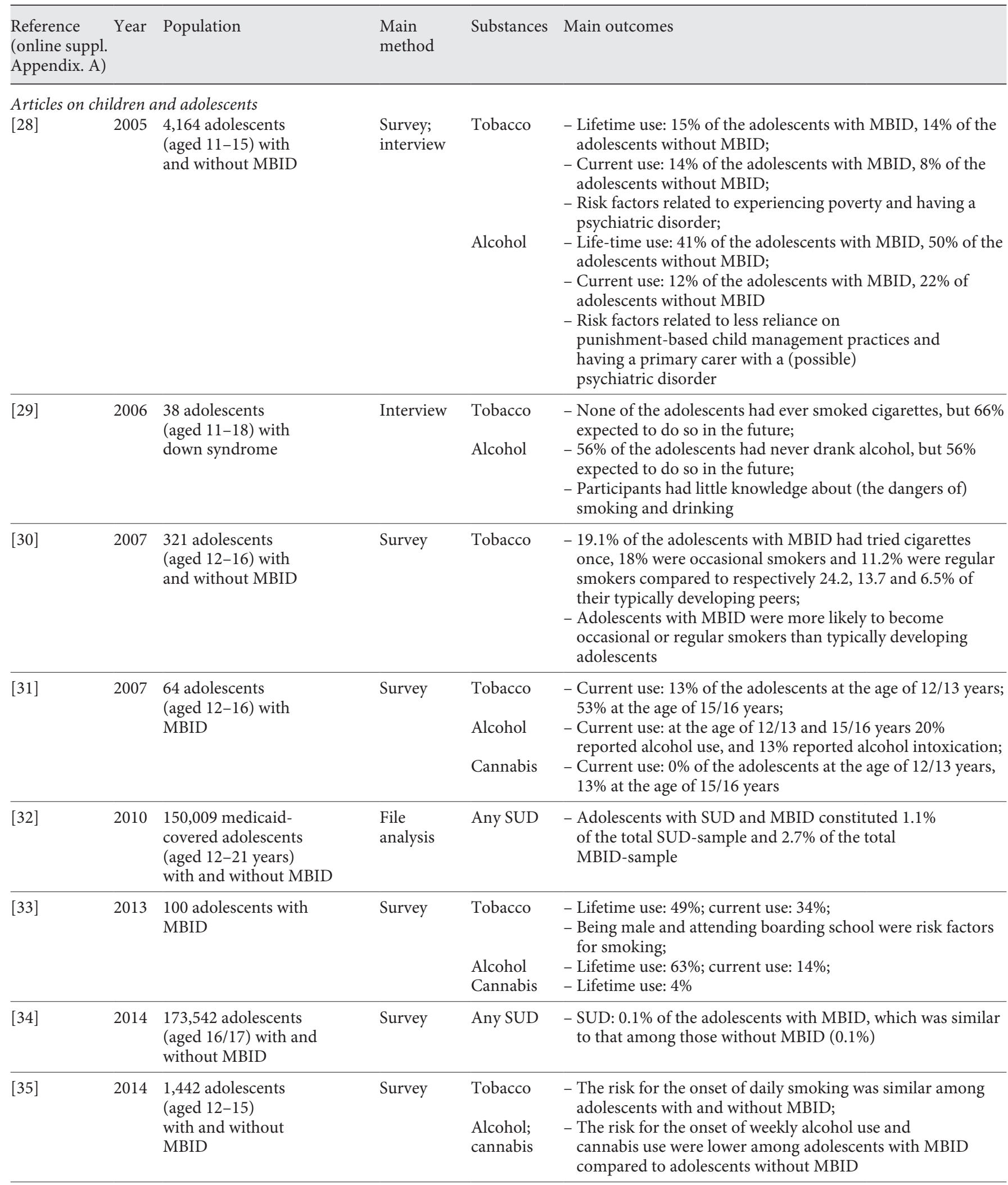


Table 1. (continued)

\begin{tabular}{|c|c|c|c|c|c|}
\hline $\begin{array}{l}\text { Reference } \\
\text { (online suppl. } \\
\text { Appendix. A) }\end{array}$ & Year & Population & $\begin{array}{l}\text { Main } \\
\text { method }\end{array}$ & Substances & Main outcomes \\
\hline [37] & 2016 & $\begin{array}{l}18,49511 \text {-year } \\
\text { old children with } \\
\text { and without MBID }\end{array}$ & Survey & Alcohol & $\begin{array}{l}\text { - Lifetime use: } 15.8 \% \text { of the children with MBID ever had an } \\
\text { alcoholic drink, } 1.2 \% \text { had ever been intoxicated, and } 3.4 \% \\
\text { had ever engaged in binge drinking compared to respectively } \\
\text { 13.2, 1.0, and } 0.8 \% \text { of the children without MBID; } \\
\text { - Differences between children with and without MBID for } \\
\text { binge drinking and having been intoxicated disappeared } \\
\text { when controlling for socio-economic position; } \\
\text { - Children with MBID had a more positive attitude } \\
\text { towards the benefits, and a less negative attitude towards the } \\
\text { costs of drinking alcohol; } \\
\text { - Risk factors for problematic alcohol use were smoking and } \\
\text { having friends who used alcohol }\end{array}$ \\
\hline [38] & 2016 & $\begin{array}{l}210 \text { adolescents } \\
\text { (aged } 12-15 \text { years old) with } \\
\text { MBID }\end{array}$ & Survey & $\begin{array}{l}\text { Tobacco } \\
\text { Alcohol }\end{array}$ & $\begin{array}{l}\text { - Lifetime use: } 49.8 \% \text {, smoking initiation before the age of } 10 \\
\text { years was } 6 \% \text {; } \\
\text { - Lifetime use: } 75.4 \%, 15 \% \text { of the adolescents had their first } \\
\text { drink before the age of } 10 \text {; } \\
\text { - Being male was a risk factor for alcohol use }\end{array}$ \\
\hline [39] & 2017 & $\begin{array}{l}69 \text { adolescents (aged } 12-16 \\
\text { years old) with mild to } \\
\text { moderate ID }\end{array}$ & Survey & $\begin{array}{l}\text { Tobacco } \\
\text { Alcohol }\end{array}$ & $\begin{array}{l}\text { - Lifetime use: } 24.6 \% \\
\text { - Lifetime use: } 59.4 \% \text {; } \\
\text { - Participants had little knowledge about (the dangers of) } \\
\text { smoking and drinking }\end{array}$ \\
\hline [41] & 2017 & $\begin{array}{l}658 \text { adolescents } \\
\text { with and without } \\
\text { MBID }\end{array}$ & Survey & Alcohol & $\begin{array}{l}\text { - Lifetime use: } 63.5 \% \text { of the adolescents with MBID was } \\
63.5 \% \text {; } 79.9 \% \text { of the adolescents without MBID; } \\
\text { - There were no differences between adolescents with and } \\
\text { without MBID in age of first use; } \\
\text { - When adolescents with MBID start drinking, they are at a } \\
\text { higher risk for problematic alcohol use than adolescents } \\
\text { without MBID }\end{array}$ \\
\hline [42] & 2017 & $\begin{array}{l}205,899 \\
\text { adolescents } \\
\text { with mild to } \\
\text { severe ID }\end{array}$ & Survey & $\begin{array}{l}\text { Tobacco } \\
\text { Alcohol } \\
\text { Illicit drugs }\end{array}$ & $\begin{array}{l}\text { - Current use: } 15.2 \% \text {; } \\
\text { - Current use: } 15.6 \% \text {; } \\
\text { - Current use: } 2.4 \% \text {; } \\
\text { - Receiving a social skills or life skills class and SU prevention } \\
\text { were protective factors for tobacco use; } \\
\text { - Receiving SU prevention, being female and not being } \\
\text { suspended/expelled from school were protective factors for } \\
\text { alcohol use }\end{array}$ \\
\hline
\end{tabular}


Table 1. (continued)

\begin{tabular}{|c|c|c|c|c|c|}
\hline $\begin{array}{l}\text { Reference } \\
\text { (online suppl. } \\
\text { Appendix. A) }\end{array}$ & Year & Population & $\begin{array}{l}\text { Main } \\
\text { method }\end{array}$ & Substances & Main outcomes \\
\hline [44] & $\begin{array}{l}\text { In } \\
\text { press }\end{array}$ & $\begin{array}{l}15,240 \text { adolescents } \\
\text { (aged } 13-20 \text { ) with } \\
\text { and without mild to } \\
\text { moderate ID }\end{array}$ & Survey & $\begin{array}{l}\text { Alcohol } \\
\text { Cannabis }\end{array}$ & $\begin{array}{l}\text { - Lifetime use: } 28 \% \text { of the males with ID } 28 \%, 22 \% \text { of the } \\
\text { males without ID, } 22 \% \text { of the females with ID, } 30 \% \text { of the } \\
\text { females without ID; } \\
\text { - Lifetime use: } 62 \% \text { of the males with ID, } 80 \% \text { of the males } \\
\text { without ID, } 46 \% \text { of the females with ID, } 80 \% \text { of the females } \\
\text { without ID; } \\
\text { - Lifetime use: } 12 \% \text { of the males with ID, } 11 \% \text { of the males } \\
\text { without ID, } 6 \% \text { of the females with ID, } 9 \% \text { of the females } \\
\text { without ID; } \\
\text { - Being bullied and spending spare time with friends were risk } \\
\text { factors of SU(D) among adolescents with MBID }\end{array}$ \\
\hline $\begin{array}{l}\text { Articles on juve } \\
{[45]}\end{array}$ & $\begin{array}{l}\text { enile of } \\
2012\end{array}$ & $\begin{array}{l}628 \text { juvenile } \\
\text { offenders with } \\
\text { and without MBID }\end{array}$ & $\begin{array}{l}\text { File } \\
\text { analysis }\end{array}$ & $\begin{array}{l}\text { Alcohol } \\
\text { Illicit drugs }\end{array}$ & $\begin{array}{l}\text { - Alcohol use disorder: } 21 \% \text { of the juvenile offenders } \\
\text { with MBID; } 34 \% \text { of the juvenile offenders without MBID; } \\
\text { - Illicit drug use disorder: } 29 \% \text { of the juvenile offenders } \\
\text { with MBID; } 47 \% \text { of the juvenile offenders without MBID; } \\
\text { - While the prevalence among juvenile offenders with } \\
\text { MBID was lower than that among those without MBID, } \\
\text { alcohol and drugs contributed to criminal behaviour in } \\
\text { similar rates }\end{array}$ \\
\hline [46] & 2013 & $\begin{array}{l}12,186 \text { juvenile } \\
\text { offenders with and } \\
\text { without MBID }\end{array}$ & $\begin{array}{l}\text { File } \\
\text { analysis }\end{array}$ & $\begin{array}{l}\text { Alcohol } \\
\text { Cannabis } \\
\text { Illicit drugs }\end{array}$ & $\begin{array}{l}\text { - Alcohol use disorder: } 12.6 \% \text { of the juvenile offenders } \\
\text { with MBID; } 15.2 \% \text { of the juvenile offenders without } \\
\text { MBID; } \\
\text { - Cannabis use disorder: } 8.8 \% \text { of the juvenile offenders } \\
\text { with MBID; } 11.0 \% \text { of the juvenile offenders without } \\
\text { MBID; } \\
\text { - Illicit drug use disorder: } 11.7 \% \text { of the juvenile offenders } \\
\text { with MBID; } 19.0 \% \text { of the juvenile offenders without } \\
\text { MBID; } \\
\text { - Borderline intellectual functioning was a risk factor for SUD }\end{array}$ \\
\hline [47] & 2014 & $\begin{array}{l}628 \text { juvenile } \\
\text { offenders with } \\
\text { and without MBID }\end{array}$ & $\begin{array}{l}\text { File } \\
\text { analysis }\end{array}$ & Any SU & $\begin{array}{l}\text { - There were no differences between juvenile offenders } \\
\text { with and without MBID in the impact of SU on recidivism }\end{array}$ \\
\hline [48] & 2017 & $\begin{array}{l}108 \text { educators working } \\
\text { with } 12 / 13 \text { year olds } \\
\text { with mild to } \\
\text { moderate ID in } \\
\text { correctional schools }\end{array}$ & $\begin{array}{l}\text { Interview; } \\
\text { survey }\end{array}$ & Any SUD & $\begin{array}{l}\text { - Teachers rated the likelihood of the child being at risk for } \\
\text { SUD on average with } 3.5 \text { points on a } 5 \text { point scale }\end{array}$ \\
\hline [49] & 2018 & $\begin{array}{l}146 \text { juvenile } \\
\text { offenders with } \\
\text { and without MBID }\end{array}$ & $\begin{array}{l}\text { File } \\
\text { analysis }\end{array}$ & $\begin{array}{l}\text { Alcohol } \\
\text { Illicit dugs }\end{array}$ & $\begin{array}{l}\text { - Alcohol use disorder: } 30.8 \% \text { of the juvenile offenders with } \\
\text { MBID; } 33.7 \% \text { of the juvenile offenders without MBID; } \\
\text { - Drug use disorder: } 70.4 \% \text { of the juvenile offenders with } \\
\text { MBID; } 74.7 \% \text { of the juvenile offenders without MBID; } \\
\text { - } 40.9 \% \text { of the juvenile offenders with MBID were under the } \\
\text { influence of alcohol or drugs at the time of the offense, } \\
\text { compared with } 60 \% \text { of the juvenile offenders without MBID; } \\
\text { - There were no differences between juvenile offenders with } \\
\text { and without MBID in prevalence of SUD }\end{array}$ \\
\hline
\end{tabular}


Table 1. (continued)

\begin{tabular}{|c|c|c|c|c|c|}
\hline $\begin{array}{l}\text { Reference } \\
\text { (online suppl. } \\
\text { Appendix. A) }\end{array}$ & Year & Population & $\begin{array}{l}\text { Main } \\
\text { method }\end{array}$ & Substances & Main outcomes \\
\hline$[50]$ & 2000 & $\begin{array}{l}540 \text { adults with } \\
\text { MBID receiving } \\
\text { ID-care }\end{array}$ & Survey & Tobacco & $\begin{array}{l}\text { - Current use: } 2-12 \% \text {; } \\
\text { - Predictors of smoking related to being more able, being } \\
\text { male, not living in a village community, and living in a } \\
\text { setting with less sophisticated procedures for staff support } \\
\text { - Current use: } 27-55 \%\end{array}$ \\
\hline [51] & 2004 & $\begin{array}{l}6,902 \text { adults with } \\
\text { and without MBID }\end{array}$ & Survey & Tobacco & $\begin{array}{l}\text { - Current use: } 17.8 \% \text { of the individuals with MBID, which was } \\
\text { similar to the prevalence among individuals with other } \\
\text { disabilities }(28.5 \%) \text { and no disabilities }(24.8 \%)\end{array}$ \\
\hline [52] & 2004 & $\begin{array}{l}435 \text { adults with ID } \\
\text { receiving ID-care }\end{array}$ & Interview & Tobacco & $\begin{array}{l}\text { - Current use: } 6.2 \% \text {; } \\
\text { - } 21 \text { individuals had given up smoking, most often because of } \\
\text { the development of health-related symptoms; } \\
\text { - Risk factors related to level of ID (MBID) and place of } \\
\text { residence (hospital, staffed housing); } \\
\text { - Participants had little knowledge about (the dangers of) smoking }\end{array}$ \\
\hline [53] & 2007 & $\begin{array}{l}1,023 \text { adults with } \\
\text { mild to profound ID }\end{array}$ & Survey & Any SUD & $\begin{array}{l}\text { - The prevalence of SUD was } 0.8 \% \text { of the total sample, and } \\
1.8 \% \text { of the individuals with MBID }\end{array}$ \\
\hline [54] & 2007 & $\begin{array}{l}651 \text { adults with } \\
\text { mild to profound ID }\end{array}$ & Survey & Any SUD & - The 2 -year incidence rate for SUD was $0.3 \%$ \\
\hline [55] & 2007 & 10 adults with MBID & Interview & Any SUD & $\begin{array}{l}\text { - People often used substances to cope with negative life } \\
\text { experiences, including psychological trauma and } \\
\text { experienced social distance from their community; } \\
\text { - People often experienced severe negative consequences of } \\
\text { SU, including physiological and psychological effects, } \\
\text { financial problems and deterioration of relationships with } \\
\text { meaningful others }\end{array}$ \\
\hline [57] & 2008 & $\begin{array}{l}371 \text { adults with MBID } \\
\text { receiving psychiatric } \\
\text { treatment }\end{array}$ & $\begin{array}{l}\text { File } \\
\text { analysis }\end{array}$ & Any SUD & - SUD: $5.9 \%$ \\
\hline [58] & 2008 & $\begin{array}{l}186 \text { adults with } \\
\text { down syndrome }\end{array}$ & Survey & $\begin{array}{l}\text { Any SUD } \\
\text { Tobacco }\end{array}$ & $\begin{array}{l}\text { - The prevalence of SUD was } 0.5 \% \text {, the } 2 \text {-year incidence of } \\
\text { SUD was } 0 \% \text {; } \\
\text { - Current use: } 98.4 \%\end{array}$ \\
\hline [59] & 2008 & $\begin{array}{l}155 \text { adults (aged } 40+\text { ) } \\
\text { with MBID }\end{array}$ & $\begin{array}{l}\text { Clinical } \\
\text { assessment }\end{array}$ & Tobacco & $\begin{array}{l}\text { - Lifetime use: } 11 \% \text {; } \\
\text { - Current use: } 6 \%\end{array}$ \\
\hline$[60]$ & 2009 & $\begin{array}{l}39 \text { adults with } \\
\text { MBID receiving } \\
\text { ID-care }\end{array}$ & $\begin{array}{l}\text { File } \\
\text { analysis }\end{array}$ & Any SUD & $\begin{array}{l}\text { - SUD: } 46 \% \text {; } \\
\text { - With the exception of palliative coping reactions, there were } \\
\text { no differences in coping strategies and adaptive skills } \\
\text { between those with and without SUD; } \\
\text { - SUD was associated with higher rates of behavioural and } \\
\text { emotional problems }\end{array}$ \\
\hline [61] & 2009 & $\begin{array}{l}1,097 \text { adults with } \\
\text { MBID }\end{array}$ & $\begin{array}{l}\text { Clinical } \\
\text { assessment }\end{array}$ & Tobacco & $\begin{array}{l}\text { - Lifetime use: } 27.2 \% \text {; } \\
\text { - Current use: } 17.3 \%\end{array}$ \\
\hline
\end{tabular}


Table 1. (continued)

\begin{tabular}{|c|c|c|c|c|c|}
\hline $\begin{array}{l}\text { Reference } \\
\text { (online suppl. } \\
\text { Appendix. A) }\end{array}$ & Year & Population & $\begin{array}{l}\text { Main } \\
\text { method }\end{array}$ & Substances & Main outcomes \\
\hline [64] & 2010 & $\begin{array}{l}78 \text { adults with MBID } \\
\text { receiving psychiatric } \\
\text { treatment }\end{array}$ & $\begin{array}{l}\text { File } \\
\text { analysis }\end{array}$ & Any SUD & $\begin{array}{l}\text { - } 3.8 \% \text { was diagnosed with SUD, and } 19.2 \% \text { of the sample had } \\
\text { a history of substance abuse; } \\
\text { - Forensic involvement was a risk factor for SUD }\end{array}$ \\
\hline [65] & 2011 & $\begin{array}{l}115 \text { adults with } \\
\text { MBID receiving } \\
\text { ID-care }\end{array}$ & $\begin{array}{l}\text { File } \\
\text { analysis }\end{array}$ & Any SU(D) & $\begin{array}{l}\text { - Lifetime SU: } 13 \% \text {, current SU: } 12.2 \% \text {; } \\
\text { - Lifetime SUD: } 15 \% \text {, current SUD: } 8.1 \% \text {; } \\
\text { - Being male, having MBID, and having forensic involvement } \\
\text { were risk factors for SU(D) }\end{array}$ \\
\hline [67] & 2011 & $\begin{array}{l}1,253 \text { adults with } \\
\text { mild to profound ID }\end{array}$ & Survey & $\begin{array}{l}\text { Tobacco } \\
\text { Alcohol }\end{array}$ & $\begin{array}{l}\text { - Current use: } 9.9 \% \text {; } \\
\text { - An older age was a risk factor for smoking; } \\
\text { - Current use: } 35.4 \% \text {, with } 1.9 \% \text { of the sample drinking daily; } \\
\text { - Drinking frequency was related to older age, while drinking } \\
\text { heavily was associated with a younger age }\end{array}$ \\
\hline [68] & 2011 & 751 adults with MBID & $\begin{array}{l}\text { Survey } \\
\text { (by } \\
\text { informant) }\end{array}$ & Any SUD & $\begin{array}{l}\text { - SUD: } 3.4 \% \text {; } \\
\text { - Having SUD was related to more frequent visits to the } \\
\text { emergency department }\end{array}$ \\
\hline [69] & 2011 & $\begin{array}{l}2,218 \text { adults with and without } \\
\text { MBID receiving psychiatric } \\
\text { treatment }\end{array}$ & $\begin{array}{l}\text { File } \\
\text { analysis }\end{array}$ & Any SUD & $\begin{array}{l}\text { - SUD: } 11 \% \text { of the forensic patients with MBID; } 5.0 \% \text { of the } \\
\text { non-forensic patients with MBID; } 28.3 \% \text { of the forensic } \\
\text { patients without MBID; } \\
\text { - Having MBID was a risk factor for SUD, while forensic } \\
\text { involvement was not }\end{array}$ \\
\hline [71] & 2013 & $\begin{array}{l}46,023 \text { households } \\
\text { with and without } \\
\text { parents with MBID }\end{array}$ & Survey & $\begin{array}{l}\text { Tobacco } \\
\text { Alcohol } \\
\text { Illicit drugs }\end{array}$ & $\begin{array}{l}\text { - Current use: } 52 \% \text { of the parents with MBID; } 20-40 \% \text { of the } \\
\text { parents without MBID; } \\
\text { - Alcohol use disorder: } 12-14 \% \text { of the parents with MBID; } \\
\text { 1-7\% of the parents without MBID; } \\
\text { - Drug use disorder: } 9-15 \% \text { of the parents with MBID; } 1-7 \% \\
\text { of the parents without MBID; } \\
\text { - The higher risk of exposure to environmental adversities } \\
\text { explained the higher prevalence of SUD among parents with } \\
\text { MBID }\end{array}$ \\
\hline [72] & 2014 & $\begin{array}{l}54,585 \text { adults with } \\
\text { and without MBID }\end{array}$ & Survey & Alcohol & $\begin{array}{l}\text { - Lifetime use: } 76.2 \% \text { of the adults with MBID; } 56.0 \% \text { of the } \\
\text { adults without MBID; } \\
\text { - Current use: } 55.7 \% \text { of the adults with MBID; } 26.2 \% \text { of the } \\
\text { adults without MBID; } \\
\text { - Current daily use: } 9.4 \% \text { of the adults with MBID; } 4.7 \% \text { of the } \\
\text { adults without MBID; } \\
\text { - The risk of tobacco and alcohol use was higher among adults } \\
\text { with MBID compared to those without MBID, which may be } \\
\text { attributed to poorer living conditions }\end{array}$ \\
\hline
\end{tabular}


Table 1. (continued)

\begin{tabular}{|c|c|c|c|c|c|}
\hline $\begin{array}{l}\text { Reference } \\
\text { (online suppl. } \\
\text { Appendix. A) }\end{array}$ & Year & Population & $\begin{array}{l}\text { Main } \\
\text { method }\end{array}$ & Substances & Main outcomes \\
\hline [74] & 2014 & $\begin{array}{l}88 \text { adults with MBID } \\
\text { and SUD receiving } \\
\text { ID-care; } 114 \text { adults } \\
\text { with MBID and SUD } \\
\text { receiving addiction care }\end{array}$ & $\begin{array}{l}\text { File } \\
\text { analysis }\end{array}$ & Any SUD & $\begin{array}{l}\text { - The percentage of MBID was } 5.7 \% \text { among individuals } \\
\text { receiving addiction care; } \\
\text { - The percentage of SUD was } 4.5 \% \text { among individuals } \\
\text { receiving ID-care; } \\
\text { - The limited overlap between the } 2 \text { sources indicates an } \\
\text { underestimation of the prevalence }\end{array}$ \\
\hline [75] & 2015 & $\begin{array}{l}40 \text { adults with MBID } \\
\text { receiving ID-care }\end{array}$ & Survey & Alcohol & $\begin{array}{l}\text { - Alcohol use disorder: } 20.0-22.5 \% \text {; } \\
\text { - Alcohol and tobacco use are often overlooked and remain } \\
\text { undetected }\end{array}$ \\
\hline [77] & 2017 & $\begin{array}{l}7,936 \text { adults (age } 55+\text { ) with } \\
\text { MBID }\end{array}$ & $\begin{array}{l}\text { File } \\
\text { analysis }\end{array}$ & Any SUD & $\begin{array}{l}\text { - SUD: } 2.3 \% \text { ( } 2 \% \text { among women, } 3 \% \text { among men); } \\
\text { - Being male was a risk factor for SUD }\end{array}$ \\
\hline [78] & 2017 & $\begin{array}{l}16 \text { adults with mild to } \\
\text { moderate ID }\end{array}$ & Interview & Any SU(D) & $\begin{array}{l}\text { - Being young, susceptibility to peer pressure, and negative role } \\
\text { models (important others engaging in SU) were risk factors } \\
\text { for SU(D); } \\
\text { - Most participants had a basic understanding of (the dangers } \\
\text { of) smoking }\end{array}$ \\
\hline [79] & 2017 & $\begin{array}{l}8,656 \text { adults } \\
\text { (age } 50+\text { ) with } \\
\text { and without MBID }\end{array}$ & Survey & Tobacco & $\begin{array}{l}\text { - Lifetime use: } 19 \% \text { of the adults with MBID; } 54.4 \% \text { of the } \\
\text { adults without MBID; } \\
\text { - Current use: } 10 \% \text { of the adults with MBID; } 18.2 \% \text { of the } \\
\text { adults without MBID; } \\
\text { - Current frequent alcohol use: } 2.5 \% \text { of the adults with MBID; } \\
22.4 \% \text { of the adults without MBID; } \\
\text { - The prevalence of SU among adults with MBID was lower } \\
\text { than that among adults without MBID }\end{array}$ \\
\hline [81] & 2017 & $\begin{array}{l}112 \text { adults with MBID } \\
\text { receiving ID-care }\end{array}$ & $\begin{array}{l}\text { Survey; } \\
\text { biomarkers }\end{array}$ & $\begin{array}{l}\text { Tobacco } \\
\text { Alcohol } \\
\text { Cannabis } \\
\text { Stimulants }\end{array}$ & $\begin{array}{l}\text { - Lifetime use: } 86.6 \% \text {; current use: } 66.1 \% \text {; } \\
\text { - Lifetime use: } 97.3 \% \text {; current use: } 25.9 \% \text {; } \\
\text { - Lifetime use: } 59.8 \% \text {; current use: } 13.4 \% \text {; } \\
\text { - Lifetime use: } 21.4 \% \text {; current use: } 0 \%\end{array}$ \\
\hline [82] & 2017 & $\begin{array}{l}419 \text { adults with } \\
\text { MBID receiving } \\
\text { ID-care }\end{array}$ & Survey & $\begin{array}{l}\text { Tobacco } \\
\text { Alcohol } \\
\text { Cannabis } \\
\text { Stimulants }\end{array}$ & $\begin{array}{l}\text { - Lifetime use: } 83.1 \% \text {; current use: } 61.6 \% \text {; } \\
\text { - Lifetime use: } 93.8 \% \text {, current use: } 63.7 \% \text {; } \\
\text { - Lifetime use: } 47.0 \% \text {; current use: } 14.6 \% \text {; } \\
\text { - Lifetime use: } 15.8 \% \text {; current use: } 1.2 \% \text {; } \\
\text { - SU initiation occurred mainly during adolescence; } \\
\text { - Gender (male), age (young), lack of daytime activities, SU } \\
\text { picture recognition, a positive attitude towards SU, and SU } \\
\text { by significant others were risk factors for SU(D), whereas } \\
\text { living arrangements and level of ID were not }\end{array}$ \\
\hline
\end{tabular}


Table 1. (continued)

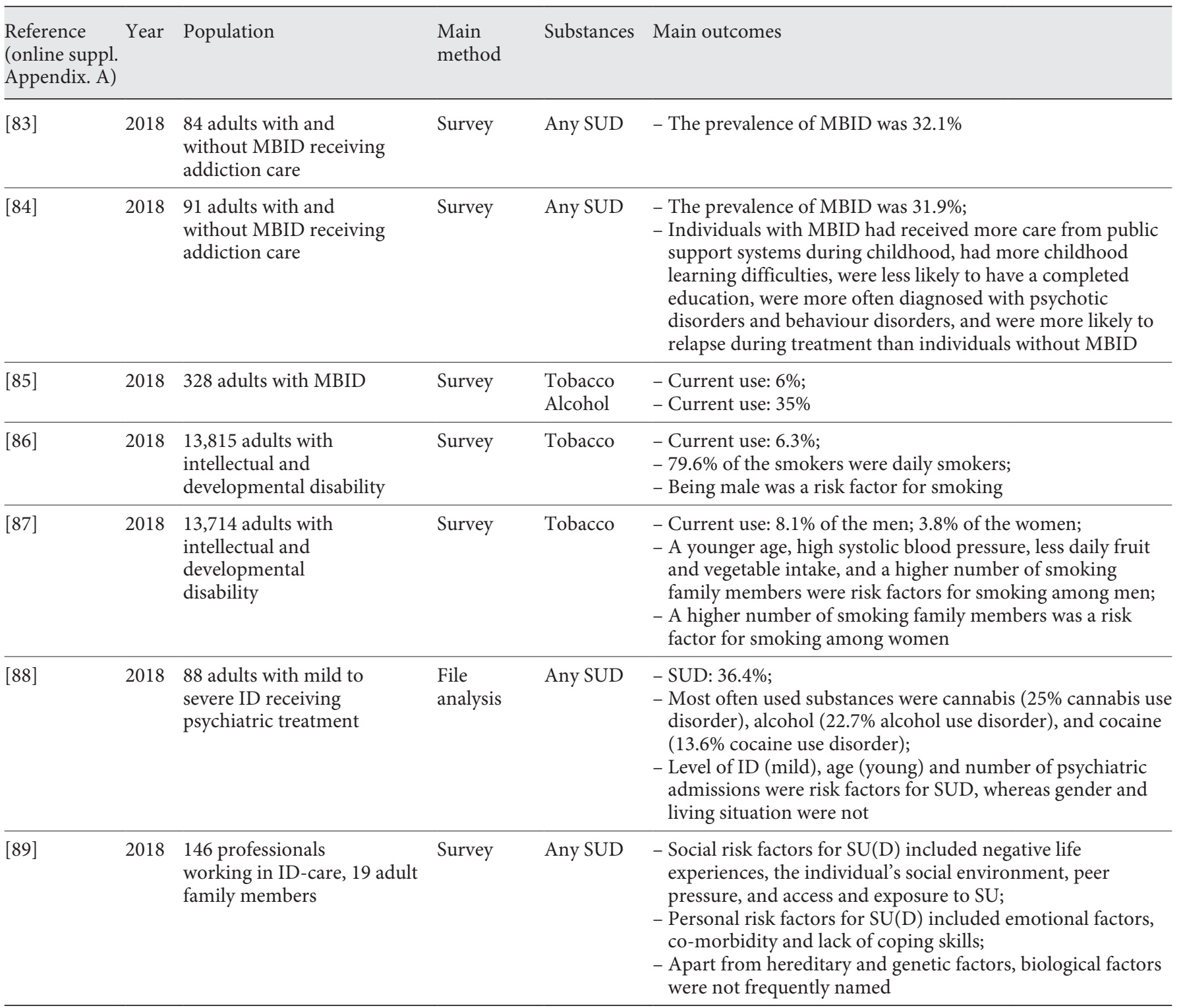

Articles on offenders

200160 offenders

with MBID
Survey

Alcohol; $\quad-60 \%$ of the offenders were under the influence of substances illicit drugs during their offense (33\% alcohol, 6.6\% illicit drugs, 20\% alcohol and illicit drugs);

- SU(D) was associated with various sorts of offending behaviour, especially assault, property damage, and endangering life;

- Offenders were more knowledgeable about the legal implications and dangers of SU than non-offenders

\begin{tabular}{|c|c|c|c|c|c|}
\hline [91] & 2003 & $\begin{array}{l}276 \text { offenders with and } \\
\text { without ID and a } \\
\text { co-occurring psychiatric } \\
\text { disorder }\end{array}$ & $\begin{array}{l}\text { File } \\
\text { analysis }\end{array}$ & Any SUD & $\begin{array}{l}-41.2 \% \text { of the offenders with ID had SUD, } 29.4 \% \text { had no } \\
\text { history of SUD, and } 23.5 \% \text { had an unknown SU-history }\end{array}$ \\
\hline
\end{tabular}


Table 1. (continued)

\begin{tabular}{|c|c|c|c|c|c|}
\hline $\begin{array}{l}\text { Reference } \\
\text { (online suppl. } \\
\text { Appendix. A) }\end{array}$ & Year & Population & $\begin{array}{l}\text { Main } \\
\text { method }\end{array}$ & Substances & Main outcomes \\
\hline [95] & 2009 & $\begin{array}{l}44 \text { offenders } \\
\text { with MBID }\end{array}$ & File analysis & Any SUD & $\begin{array}{l}\text { - SUD: } 68 \% \text {; } \\
\text { - } 36 \% \text { of the sample also had a co-occurring psychiatric } \\
\text { disorder; } \\
-45 \% \text { of the offenders were intoxicated during the crime }\end{array}$ \\
\hline [98] & 2013 & $\begin{array}{l}1,325 \text { offenders } \\
\text { with and without } \\
\text { MBID }\end{array}$ & Survey & Any SUD & $\begin{array}{l}\text { - Lifetime SUD: } 11.2 \% \text { of the offenders with MBID was } 11.2 \% \text {, } \\
\text { which was similar to that among those without MBID } \\
(9.0 \%) \text {; } \\
\text { - Current SUD: } 8.6 \% \text { of the offenders with MBID, which was } \\
\text { higher than that among those without MBID }(2.2 \%)\end{array}$ \\
\hline [100] & 2015 & $\begin{array}{l}1,325 \text { offenders } \\
\text { with and without } \\
\text { MBID }\end{array}$ & Survey & $\begin{array}{l}\text { Poly-drug } \\
\text { use }\end{array}$ & $\begin{array}{l}\text { - Lifetime use: } 85.2 \% \text { of the offenders with MBID; } 79.6 \% \text { of } \\
\text { the offenders without MBID; } \\
\text { - Current use: } 86.6 \% \text { of the offenders with MBID; } 78.7 \% \text { of the } \\
\text { offenders without MBID; } \\
\text { - Lifetime use: } 81.2 \% \text { of the offenders with MBID; } 81.7 \% \text { of } \\
\text { the offenders without MBID; } \\
\text { - Current use: } 10.8 \% \text { of the offenders with MBID; } 10.0 \% \text { of the } \\
\text { offenders without MBID; } \\
\text { - Lifetime use: } 52.9 \% \text { of the offenders with MBID; } 53.0 \% \text { of } \\
\text { the offenders without MBID; } \\
\text { - Current use: } 26.9 \% \text { of the offenders with MBID; } 26.2 \% \text { of the } \\
\text { offenders without MBID; } \\
\text { - Lifetime use: } 28.0 \% \text { of the offenders with MBID; } 27.8 \% \text { of } \\
\text { the offenders without MBID; } \\
\text { - Current use: } 9.9 \% \text { of the offenders with MBID; } 9.1 \% \text { of the } \\
\text { offenders without MBID; } \\
\text { - Rates of SU and SU-related harm were similar between } \\
\text { offenders with and without MBID }\end{array}$ \\
\hline
\end{tabular}


Table 1. (continued)

\begin{tabular}{|c|c|c|c|c|c|}
\hline $\begin{array}{l}\text { Reference } \\
\text { (online suppl. } \\
\text { Appendix. A) }\end{array}$ & Year & Population & $\begin{array}{l}\text { Main } \\
\text { method }\end{array}$ & Substances & Main outcomes \\
\hline [101] & 2016 & $\begin{array}{l}449 \text { offenders with } \\
\text { and without MBID }\end{array}$ & Interview & $\begin{array}{l}\text { Alcohol + } \\
\text { illicit } \\
\text { drugs }\end{array}$ & $\begin{array}{l}\text { - Lifetime use: } 65 \% \text { of the offenders with MBID; } 74 \% \text { of the } \\
\text { offenders without MBID; } \\
\text { - Current use: } 22 \% \text { of the offenders with MBID; } 32 \% \text { of the } \\
\text { offenders without MBID; } \\
\text { - Lifetime use: } 59 \% \text { of the offenders with MBID; } 67 \% \text { of the } \\
\text { offenders without MBID; } \\
\text { - Current use: } 39 \% \text { of the offenders with MBID; } 67 \% \text { of the } \\
\text { offenders without MBID; } \\
\text { - Lifetime use: } 45 \% \text { of the offenders with MBID; } 49 \% \text { of the } \\
\text { offenders without MBID; } \\
\text { - Current use: } 20 \% \text { of the offenders with MBID; } 51 \% \text { of the } \\
\text { offenders without MBID; } \\
\text { - Lifetime SU rates were similar between offenders with and } \\
\text { without MBID, rates of SU the month prior to the arrest } \\
\text { were lower among individuals with MBID; } \\
\text { - SU related to offending behaviour in } 32 \% \text { of the offenders } \\
\text { with MBID, which was a lower rate than that of offenders } \\
\text { without MBID ( } 64 \%)\end{array}$ \\
\hline [102] & 2017 & $\begin{array}{l}240 \text { offenders with } \\
\text { and without MBID }\end{array}$ & Survey & Any SUD & $\begin{array}{l}\text { - SUD: } 37.5 \% \text { of the offenders with MBID, which was similar } \\
\text { to that among offenders without MBID }(26 \%)\end{array}$ \\
\hline [103] & 2017 & $\begin{array}{l}190 \text { offenders with and } \\
\text { without MBID in a } \\
\text { forensic addiction } \\
\text { treatment centre }\end{array}$ & Survey & Any SUD & $\begin{array}{l}\text { - The prevalence of MBID was } 39 \% \text {; } \\
\text { - Offenders with MBID reported a lower desire for help than } \\
\text { offenders without MBID }\end{array}$ \\
\hline [104] & 2018 & $\begin{array}{l}91 \text { offenders with and } \\
\text { without MBID }\end{array}$ & Survey & Any SUD & - SUD: $53.3 \%$ of the offenders with MBID \\
\hline $\begin{array}{l}\text { Articles on ado } \\
{[105]}\end{array}$ & $\begin{array}{l}\text { olescent } \\
2003\end{array}$ & $\begin{array}{l}\text { ts and adults } \\
581 \text { individuals } \\
\text { with MBID }\end{array}$ & Survey & Tobacco & $\begin{array}{l}\text { - Current use: } 1.9 \% \text {; } \\
\text { - Smokers were exposed to more modelling of smoking and } \\
\text { less active discouragement of smoking than non-smokers; } \\
\text { - The majority of the smokers }(72.7 \%) \text { expressed the desire to } \\
\text { stop smoking, mainly for health reasons; } \\
\text { - Smokers and non-smokers were well aware of (the dangers } \\
\text { of) smoking in relation to their health }\end{array}$ \\
\hline [106] & 2005 & $\begin{array}{l}53 \text { individuals } \\
\text { with MBID }\end{array}$ & Interview & Tobacco & $\begin{array}{l}\text { - Lifetime use: } 71.7 \% \\
\text { - Current use: } 52.8 \%\end{array}$ \\
\hline [107] & 2006 & $\begin{array}{l}482 \text { individuals with } \\
\text { and without MBID }\end{array}$ & Interview & Tobacco & $\begin{array}{l}\text { - Current use: } 24.0 \% \text { of the individuals with MBID, which was } \\
\text { similar to the prevalence of tobacco use among those } \\
\text { without MBID }(31.7 \%) \text {; } \\
\text { - Current use: } 25.1 \% \text { of the individuals with MBID, which was } \\
\text { lower to the prevalence of alcohol use among those without } \\
\text { MBID (63.9\%) }\end{array}$ \\
\hline [108] & 2006 & $\begin{array}{l}54 \text { professionals (social } \\
\text { workers, nurses, } \\
\text { addiction workers) }\end{array}$ & Survey & Any SUD & $\begin{array}{l}\text { - The prevalence of SUD among adults with MBID known to } \\
\text { services was estimated } 0.8 \% \text { of the population; } \\
\text { - } 38.8 \% \text { of the sample was diagnosed with or was suspected to } \\
\text { have a co-occurring psychiatric disorder }\end{array}$ \\
\hline [109] & 2007 & $\begin{array}{l}157 \text { carers of } \\
\text { individuals with } \\
\text { mild to profound ID }\end{array}$ & Survey & $\begin{array}{l}\text { Tobacco } \\
\text { Alcohol }\end{array}$ & $\begin{array}{l}\text { - Current use: } 2.6 \% \text { of the total sample; } \\
\text { - Current use: } 38.2 \% \text { of the total sample }\end{array}$ \\
\hline
\end{tabular}


Table 1. (continued)

\begin{tabular}{|c|c|c|c|c|c|}
\hline $\begin{array}{l}\text { Reference } \\
\text { (online suppl. } \\
\text { Appendix. A) }\end{array}$ & Year & Population & $\begin{array}{l}\text { Main } \\
\text { method }\end{array}$ & Substances & Main outcomes \\
\hline [110] & 2010 & $\begin{array}{l}376,090 \text { Medicaid-covered } \\
\text { individuals (age } 12+\text { ) with } \\
\text { mild to profound ID }\end{array}$ & $\begin{array}{l}\text { File } \\
\text { analysis }\end{array}$ & Any SUD & $\begin{array}{l}\text { - The prevalence of SUD in the total sample was } 2.6 \% \text {, the } \\
\text { prevalence of SUD among those with MBID was } 5.2 \% \text {; } \\
\text { - Being male, a younger age, being non-White, and having a } \\
\text { co-occurring psychiatric disorder were risk factors for SUD }\end{array}$ \\
\hline [111] & 2010 & $\begin{array}{l}924,554 \text { Medicaid-covered } \\
\text { individuals (age } 12+\text { ) with } \\
\text { and without MBID }\end{array}$ & $\begin{array}{l}\text { File } \\
\text { analysis }\end{array}$ & Any SUD & $-2.6 \%$ of the MBID-sample met the criteria of SUD \\
\hline [112] & 2011 & $\begin{array}{l}39 \text { professionals } \\
\text { working in } \\
\text { ID-care }\end{array}$ & Survey & $\begin{array}{l}\text { Alcohol } \\
\text { Cannabis } \\
\text { Illicit drugs }\end{array}$ & $\begin{array}{l}\text { - Lifetime use: } 22-90 \% \text {; current use: } 22-84 \% \text {; problematic use: } \\
\text { 1-6\%; } \\
\text { - Lifetime use: } 8-33 \% \text {; current use: } 3-23 \% \text {; problematic use: } \\
\text { 0-7\%; } \\
\text { - Lifetime use: } 0-7 \% \text {; current use: } 0-2 \% \text {; problematic use: } \\
\text { 0-1\% }\end{array}$ \\
\hline [113] & 2014 & $\begin{array}{l}387 \text { homeless individuals } \\
\text { with and without MBID }\end{array}$ & Survey & Any SU(D) & $\begin{array}{l}\text { - Current SU: } 51.8 \% \text { of the individuals with MBID; } 44.7 \% \text { of } \\
\text { the individuals without MBID; } \\
\text { - Problematic SU: } 31.6 \% \text { of the individuals with MBID; } 24.7 \% \\
\text { of the individuals without MBID; } \\
\text { - SUD: } 28.9 \% \text { of the individuals with MBID; } 18.4 \% \text { of the } \\
\text { individuals without MBID; } \\
\text { - While rates of (problematic) SU were similar across } \\
\text { individuals with and without MBID, individuals with MBID } \\
\text { were at higher risk for SUD }\end{array}$ \\
\hline [114] & 2014 & $\begin{array}{l}104 \text { professionals } \\
\text { working in ID-care or } \\
\text { addiction medicine }\end{array}$ & Survey & Any SU(D) & $\begin{array}{l}\text { - SU: } 42.3 \% \\
\text { - SUD: } 57.7 \% \text {; } \\
\text { - Alcohol, cannabis and cocaine were used most often; } \\
\text { - Individuals with SUD less often had a paid job, experienced } \\
\text { more difficulties to live independently, experienced more } \\
\text { problems with personal relationships, and more often had } \\
\text { mood swings and suicide ideation }\end{array}$ \\
\hline [115] & 2017 & 270 individuals with MBID & $\begin{array}{l}\text { File } \\
\text { analysis }\end{array}$ & Any SUD & $\begin{array}{l}\text { - SUD: } 34.1 \% \text {; } \\
\text { - Individuals with SUD often showed problem behaviour, had } \\
\text { no daily activities, had a parent with psychiatric problem, } \\
\text { were exposed to inconsistent parenting, and had difficulty } \\
\text { connecting to peers }\end{array}$ \\
\hline [116] & 2017 & 118 individuals with MBID & Survey & $\begin{array}{l}\text { Alcohol } \\
\text { Cannabis } \\
\text { Illicit } \\
\text { drugs }\end{array}$ & $\begin{array}{l}\text { - Lifetime use: } 89 \% \text {; current use: } 54 \% \text {; } \\
\text { - Lifetime use: } 59 \% \text {; current use: } 22 \% \text {; } \\
\text { - Lifetime use: } 42 \% \text {; current use: } 11 \% \text {; } \\
\text { - There were no differences in prevalence rates between those } \\
\text { with borderline intellectual functioning and mild ID }\end{array}$ \\
\hline
\end{tabular}

SU, substance use; SUD, SU disorders; MBID, mild to borderline intellectual disability.

It should be noted, however, that in some subgroups of individuals with MBID the lifetime prevalence of SUD seems to be much higher compared to that in the general population. With prevalence rates up to $46.0 \%$, individuals receiving residential ID-care, for example, seem to be at risk for developing SUD [8-10]. High prevalence rates of SUD have also been reported among homeless people
(28.9\%, [11]) and individuals receiving residential psychiatric care $(36.4 \%,[12])$. In forensic samples, even higher percentages of SUD are found (generally around $10-30 \%$ in juvenile samples and $40-60 \%$ in adult samples). These studies suggest that those with comorbid psychiatric disorders, forensic involvement or severe behavioral and emotional problems are especially at risk for developing SUD. 
In addition to the abovementioned risk factors for developing SUD, a number of other risk factors have also been identified. Being male, being young, having a lower socioeconomic status, having mild or borderline ID (rather than severe or moderate ID), poor living conditions, lack of daytime activities, difficulties connecting to peers and SU by role models (e.g., staff members, parents, peers) were named most often - although not consistently across studies. In addition, a number of articles has focused on one specific risk factor for SU(D), namely, a lack of SU-related knowledge. The results of those studies are mixed. Although some conclude that individuals with MBID have little - and at best basic - knowledge about (the dangers of) smoking and drinking, others conclude that individuals with MBID are quite knowledgeable on the subject (Table 1).

\section{Prevention}

Despite the high prevalence of SU(D) among individuals with MBID, research into SUD educational and prevention programs is scarce. We have found 2 prevention programs that have been or are in the process of being studied. The first program is called "Prepared on time"; a Dutch prevention program based on the attitude - social influence - efficacy model. It was successfully piloted among adolescents with MBID and mild to moderate intellectual disability, but yielded little results regarding preventing SU initiation and attitudes towards SU. According to the authors, this can be partially attributed to the fact that quite some participants had already started to use tobacco and alcohol. The second program is called "Take it personal!"; another Dutch prevention program targeting adolescents with MBID who have initiated SU and who have a risky personality profile [13]. The effectiveness of the program is currently being studied in a randomized controlled trial.

\section{Screening and Assessment}

A similar low number of studies thus far has focused on the screening and assessment of both SU(D) and MBID (Table 2). With regard to the screening and early identification of MBID among adults with SUD, the Hayes Ability Screening Index [14] seems to be a suitable and valid instrument. This is a brief screening instrument that can be administered by staff in 5-10 min. A Wechsler Adult Intelligence Scale - third edition [15] short form might be useful to estimate intellectual functioning. This short form consists of 4 subtests (i.e., Vocabulary, Similarities, Block design, and Matrix reason- ing) and can be administered by a trained professional in about $30 \mathrm{~min}$.

With regard to screening for SU(D) among adults with MBID, self-report seems the most suitable - despite the tendency of individuals with MBID to underreport SU. To do this, the CAGE [16] and the AUDIT/ DUDIT $[17,18]$ proved to be feasible. To date, there is only one instrument specifically designed to assess SU(D) among individuals with MBID. The SU and misuse in Intellectual Disability Questionnaire [19] takes into account the needs of individuals with MBID and has successfully been used to assess SU, risk factors for SUD, and consequences of SU(D) in individuals with MBID. In addition to self-report, collateral information (such as reports from family members or professional caregivers) and biomarker analysis (such as the analysis of breath, blood or urine) can contribute to the assessment (Table 2).

\section{Treatment}

Articles on the treatment of SUD among individuals with MBID not only describe developed treatment interventions, but also cover treatment access. Individuals with MBID often experience barriers to SUD treatment access (Table 3). It has repeatedly been reported that they are less likely to initiate and engage in SUD treatment and are more likely to drop out. Available numbers suggest that only a small number of individuals with MBID and SUD have received specialized SUD treatment and that involvement of addiction medicine is often limited.

The limited research on the effectiveness of SUD treatment interventions for individuals with MBID further adds to this problem $[6,20,21]$. From the available research it can be concluded that - with minor adaptations in communication [22] - interventions based on motivational interviewing techniques seem effective in increasing the readiness to change of individuals with MBID and their motivation to enter into SUD treatment. Mindfulnessbased and other cessation programs seem effective in eliciting behavioral change and reducing SU. However, as has been concluded before $[6,20]$, the articles often remain at the level of feasibility and pilot studies of poor to moderate methodological quality, and the interventions are often short, of relatively simple nature and disregard comorbid psychiatric disorders and psychosocial problems (Table 3 ).

\section{Neuropsychology of SUD}

A specific line of research has been directed at the neuropsychological underpinnings of SUD in individuals with MBID (online suppl. Appendix A 130-138). The 
Table 2. Overview of articles on the screening and assessment of SUD in individuals with MBID, sorted by topic

\begin{tabular}{|c|c|c|c|c|}
\hline $\begin{array}{l}\text { Reference } \\
\text { (online suppl. } \\
\text { Appendix A) }\end{array}$ & Year & Population & Main method & Main outcomes \\
\hline \multicolumn{5}{|c|}{ Articles on screening and assessment of MBID } \\
\hline [94] & 2008 & $\begin{array}{l}143 \text { offenders with and } \\
\text { without MBID }\end{array}$ & $\begin{array}{l}\text { Screening instrument } \\
\text { (HASI) }\end{array}$ & $\begin{array}{l}\text { - The convergent of the HASI was good; } \\
\text { - A cut-off value of } 80 \text { is recommended to reduce } \\
\text { the number of false positives }\end{array}$ \\
\hline$[118]$ & 2016 & 117 adults with MBID & $\begin{array}{l}\text { Screening instrument } \\
\text { (WAIS-III short form) }\end{array}$ & $\begin{array}{l}\text { - The WAIS-III short form is a reliable and valid } \\
\text { measure to estimate full scale IQ; } \\
\text { - The WAIS-III short form is suitable for screening } \\
\text { purposes, when global estimates of IQ are } \\
\text { sufficient }\end{array}$ \\
\hline [83] & 2018 & $\begin{array}{l}84 \text { adults with and without } \\
\text { MBID receiving addiction care }\end{array}$ & $\begin{array}{l}\text { Screening instrument } \\
\text { (HASI) }\end{array}$ & $\begin{array}{l}\text { - The convergent, discriminant, and overall } \\
\text { validity of the HASI was acceptable to good }\end{array}$ \\
\hline \multicolumn{5}{|c|}{ Articles on screening and assessment of $S U(D)$} \\
\hline [75] & 2015 & $\begin{array}{l}40 \text { adult patients with MBID } \\
\text { receiving care from a } \\
\text { community ID team }\end{array}$ & $\begin{array}{l}\text { Screening instruments } \\
\text { (CAGE; AUDIT) }\end{array}$ & $\begin{array}{l}\text { - The CAGE and the AUDIT indicated the } \\
\text { prevalence of alcohol use disorder was between } \\
20.0 \text { and } 22.5 \% \text {; } \\
\text { - Using CAGE as the gold standard, the sensitivity } \\
\text { of the AUDIT was } 87.5 \% \text { and the specificity was } \\
\text { 94\%; Alcohol use and smoking are often } \\
\text { overlooked and remain undetected }\end{array}$ \\
\hline
\end{tabular}

SUD, substance use disorders; MBID, mild to borderline intellectual disability; HASI, Hayes Ability Screening Index.

overall aim of these studies was to explore the applicability of neuropsychological measures in the assessment and treatment of SUD in individuals with MBID.

Studies on cognitive biases provided inconclusive results $[23,24]$. We did not find evidence of an attentional bias or approach bias in problematic drinkers. We did find a so-called interpretation or association bias in problematic drinkers. That is, problematic drinkers were inclined to interpret ambiguous scenarios in an alcohol-related manner. In a word association task, subjects were required to finish ambiguous scenarios such as "You're at a party with your friends. 'Come on! Join us!', one of your friends says. You have no choice, everybody is ..." Problematic drinkers gave more alcohol-related answers ("drinking") than neutral answers (e.g., "dancing"). Drinking motives and IQ could predict the strength of the interpretation bias.

Studies on executive and cognitive dysfunctioning also provided inconclusive results. There were no differences in working memory capacity, inhibitory control, and verbal IQ between problematic and light drinkers. Problematic drinkers without MBID did have a lower performance IQ than light drinkers without MBID. This indicates possible difficulties in processing speed, problem solving ability, and flexibility. However, in problematic 
Table 3. Overview of articles on the treatment of SUD in individuals with MBID, sorted by topic

\begin{tabular}{lll}
\hline Reference Year Population & Main method Main outcomes \\
(online suppl. & & \\
Appendix A) & & \\
\hline
\end{tabular}

Articles on treatment access

\begin{tabular}{|c|c|c|c|c|}
\hline$[90]$ & 2001 & 60 offenders with MBID & Survey & $-23.4 \%$ of the offenders had received SUD-treatment \\
\hline [111] & 2010 & $\begin{array}{l}924,554 \text { medicaid-covered } \\
\text { individuals (age } 12+\text { ) with } \\
\text { and without MBID }\end{array}$ & File analysis & $\begin{array}{l}\text { - Individuals with MBID were less likely to initiate and } \\
\text { engage in SUD treatment, and were more likely to } \\
\text { drop out than individuals without MBID; } \\
\text { - Given the high rate of co-occurring psychiatric } \\
\text { disorders and this being positively related to treatment } \\
\text { utilization, collaboration between SUD treatment } \\
\text { providers and mental health care is advised }\end{array}$ \\
\hline
\end{tabular}

\begin{tabular}{|c|c|c|c|c|}
\hline [32] & 2010 & $\begin{array}{l}150,009 \text { Medicaid-covered } \\
\text { adolescents (aged } 12-21 \text { years) } \\
\text { with and without MBID }\end{array}$ & File analysis & $\begin{array}{l}\text { - Adolescents with MBID were less likely to initiate and } \\
\text { engage in SUD treatment, and were more likely to } \\
\text { drop out than adolescents without MBID; } \\
\text { - System integration, interdisciplinary collaboration } \\
\text { and the development of tailored SUD treatment for } \\
\text { adolescents with MBID are advised to improve } \\
\text { treatment access and utilization by adolescents with } \\
\text { MBID }\end{array}$ \\
\hline
\end{tabular}

\begin{tabular}{|c|c|c|c|c|}
\hline [119] & 2010 & $\begin{array}{l}226,974 \text { medicaid covered } \\
\text { individuals (age } 12+\text { ) with } \\
\text { and without MBID, SUD and } \\
\text { co-occurring psychiatric } \\
\text { disorders }\end{array}$ & File analysis & $\begin{array}{l}\text { - Individuals with MBID were less likely to initiate and } \\
\text { engage in SUD treatment, and were more likely to } \\
\text { drop out than individuals without MBID; } \\
\text { - Cross-system and interdisciplinary collaboration is } \\
\text { advised to improve treatment access and utilization by } \\
\text { individuals with MBID }\end{array}$ \\
\hline [97] & 2011 & $\begin{array}{l}3,142 \text { offenders with and } \\
\text { without MBID }\end{array}$ & Survey & $\begin{array}{l}\text { - Offenders with MBID less often received drug } \\
\text { education while in prison than offenders without } \\
\text { MBID }\end{array}$ \\
\hline [101] & 2016 & $\begin{array}{l}449 \text { offenders with and } \\
\text { without MBID }\end{array}$ & Interview & $\begin{array}{l}\text { - Participation in SUD treatment programs were similar } \\
\text { between offenders with and without MBID, but } \\
\text { completion of treatment programs was lower among } \\
\text { offenders with MBID }\end{array}$ \\
\hline [120] & 2016 & $\begin{array}{l}440,160 \text { Medicaid-covered } \\
\text { adults (age } 18+\text { ) with and } \\
\text { without MBID }\end{array}$ & File analysis & $\begin{array}{l}\text { - Women with MBID were equally likely to initiate } \\
\text { SUD-treatment, but less likely to engage in treatment } \\
\text { than men with MBID; } \\
\text { - Women with MBID were less likely to initiate and } \\
\text { engage in SUD treatment than women without MBID; } \\
\text { - Given the high rate of co-occurring psychiatric } \\
\text { disorders among women with MBID and this being } \\
\text { positively related to treatment utilization, } \\
\text { collaboration between ID-care, SUD treatment } \\
\text { providers, and mental health care is advised }\end{array}$ \\
\hline [121] & 2017 & $\begin{array}{l}250 \text { individuals with MBID } \\
\text { receiving long-term ID-care }\end{array}$ & File analysis & $\begin{array}{l}\text { - } 23 \% \text { of the individuals with MBID and SUD had } \\
\text { received specialized SUD treatment, suggesting a } \\
\text { treatment access barrier; } \\
\text { - A matched care approach must be taken to meet the } \\
\text { support and treatment needs of individuals with MBID }\end{array}$ \\
\hline
\end{tabular}


Table 3. (continued)

\begin{tabular}{|c|c|c|c|c|}
\hline $\begin{array}{l}\text { Reference } \\
\text { (online suppl. } \\
\text { Appendix A) }\end{array}$ & Year & Population & Main method & Main outcomes \\
\hline \multicolumn{5}{|c|}{ Articles on motivation and motivational interviewing } \\
\hline$[122]$ & 2012 & $\begin{array}{l}7 \text { adult offenders with alcohol } \\
\text { use disorder and MBID } \\
\text { admitted to a medium secure } \\
\text { setting }\end{array}$ & $\begin{array}{l}\text { Survey; } \\
\text { intervention } \\
\text { (motivational } \\
\text { group) }\end{array}$ & $\begin{array}{l}\text { - Participants gave good to very good ratings to all } \\
\text { aspects of the intervention; } \\
\text { - The intervention showed positive effects on the } \\
\text { readiness to change and self-efficacy of participants }\end{array}$ \\
\hline$[124]$ & 2017 & $\begin{array}{l}13 \text { caregivers working } \\
\text { within ID-care; } 8 \text { adults with } \\
\text { MBID receiving ID-care }\end{array}$ & $\begin{array}{l}\text { Interviews; } \\
\text { observation }\end{array}$ & $\begin{array}{l}\text { - Supporting the autonomy of clients is a core } \\
\text { characteristic for ID-care, but poses a challenge when } \\
\text { clients conduct (self-)harming or unhealthy behavior; } \\
\text { - Coercion and restriction are counterproductive and } \\
\text { endanger the relationship between the client and } \\
\text { caregiver }\end{array}$ \\
\hline
\end{tabular}

\section{Articles on mindfulness}

[125]

31 year old man with MBID

Intervention

(mindfulness-

based smoking

cessation

program)

\begin{tabular}{|c|c|c|c|}
\hline [126] & 2013 & 3 adults with MBID & $\begin{array}{l}\text { Intervention } \\
\text { (mindfulness- } \\
\text { based smoking } \\
\text { cessation } \\
\text { program) }\end{array}$ \\
\hline [127] & 2014 & 51 adults with MBID & $\begin{array}{l}\text { Intervention } \\
\text { (mindfulness- } \\
\text { based smoking } \\
\text { cessation } \\
\text { program) }\end{array}$ \\
\hline
\end{tabular}

Articles on other cessation programs

[96] $2011 \quad 79$ inpatients with MBID

in a forensic unit
Intervention

(smoking education and cessation program)
- The participant successfully reduced and eventually stopped smoking;

- The results maintained at a 3-year follow-up

- The participants successfully reduced and eventually stopped smoking;

- Mindfulness-based strategies may be effective in reducing smoking and urge to smoke

- Participants who received the mindfulness-based cessation program were more likely to reduce or quit smoking compared to those receiving treatment as usual;

- The results remained at a 1 year follow-up

- $31 \%$ of the participants quit smoking during admission;

- Participants who did not quit smoking significantly reduced their number of daily cigarettes to about one third of their baseline;

- Participants commented that the "smoking timeline" was useful in reducing or quitting smoking 
Table 3. (continued)

\begin{tabular}{|c|c|c|c|c|}
\hline $\begin{array}{l}\text { Reference } \\
\text { (online suppl. } \\
\text { Appendix A) }\end{array}$ & Year & Population & Main method & Main outcomes \\
\hline [129] & 2017 & $\begin{array}{l}30 \text { problematic drinkers } \\
\text { with MBID }\end{array}$ & $\begin{array}{l}\text { Intervention } \\
\text { (extended brief } \\
\text { intervention for } \\
\text { alcohol misuse) }\end{array}$ & $\begin{array}{l}\text { - Both participants and therapists gave the intervention } \\
\text { positive ratings; } \\
\text { - Preliminary results suggest that participants reduced } \\
\text { their alcohol consumption; } \\
\text { - The extended brief intervention seems feasible for } \\
\text { problematic drinkers with MBID }\end{array}$ \\
\hline
\end{tabular}

SU, substance use; SUD, SU disorders; MBID, mild to borderline intellectual disability.

drinkers with MBID, performance IQ was not lower than in light drinkers with MBID.

We $[23,24]$ hypothesize that methodological challenges contributed to the inconclusive results. Before these challenges have been addressed in future research, the use of cognitive bias modification procedures (aimed at reducing cognitive biases) or neuropsychological treatment protocols (aimed at improving executive functioning) to treat SUD in individuals with MBID is premature and is discouraged.

\section{Discussion}

In sum, the prevalence rates of $\mathrm{SU}(\mathrm{D})$ among individuals with MBID range from almost non-existent to highly prevalent. This could be related to methodological differences between the studies, but also to variability in vulnerability to developing SUD between subgroups. Especially, individuals with MBID - as opposed to those with moderate to severe intellectual disability - and individuals with psychiatric comorbidity or forensic involvement seem to be at risk for SU(D). Within MBID populations, it appears that because of a lack of systematic screening and assessment of SU(D), SU is often overlooked and remains undetected [25]. Those identified with SUD are probably only the "tip of the iceberg" [26]. It can be concluded that individuals with MBID are likely to be at a higher risk for developing SUD compared to those without MBID. This means that the development of more educational and prevention programs for individuals with MBID is highly needed $[7,21,27]$. Considering the early age of onset and the relative risk of SU developing into SUD in adolescents with MBID, it is important to reach them before they start using substances. Increasing substance-related knowledge, attending to the role parents and caretakers can play in modeling healthy behavior and taking into account the variety of personal risk factors might be key ingredients in this. System integration, interdisciplinary collaboration, and the development of tailored treatment for individuals with MBID are advised to improve treatment access and outcome for those who have developed SUD. Within such an approach, the wide variation of intellectual and adaptive capacities of individuals with MBID, their social support and risk factors, as well as the variety in ID care arrangements need to be taken into account.

Although the attention for SU(D) among individuals with MBID has been growing exponentially, the subject has largely been ignored by addiction medicine. Only a small number of all papers on SUD among individuals with MBID were published in addiction journals. This is surprising considering the conclusions we have drawn in this paper. There are several explanations for this neglect. One could, for instance, argue that $S U(D)$ is a rarity among those with MBID. This seems to reflect a widely held belief that individuals with MBID live their lives sheltered from the dangers of society and refrain from potentially hazardous activities, such as SU. But - even if this was ever true - this is no longer the case. It has been argued previously that due to the process of de-institu- 
tionalization the exposure to $\mathrm{SU}(\mathrm{D})$ in this group has risen [28]. One could also argue that SUD among individuals with MBID is not a problem for addiction care. In other words, this could be (or even should be) solved within ID services. However, even when ID services can provide some type of assistance targeted to SUD, ID services cannot treat severe or complex SUD. Assuming they could, based on their successful interventions in individuals with MBID and mild SU-related problems, would be similar to assuming they could perform an appendectomy, based on the fact that they can successfully remove a splinter. It is simply not their expertise. To add to this: many individuals with MBID do not need or receive any type of ID services. Assuming ID services will "fix the problem" would therefore mean individuals with MBID and SUD would not receive the help they need. Lastly, one could argue that individuals with and without MBID are similar - thereby indicating that articles specifically focusing on SUD among individuals with MBID are of no added value to the already existing knowledge base on SUD. Reality simply proves this statement wrong, given the problematic access to addiction treatment as well as the limited treatment results. In all 3 cases, SUD among individuals with MBID is simply not seen as relevant enough for professionals working in addiction medicine to be covered in these journals. By reviewing and summarizing the literature on this topic, we have shown that these statements are false. SUD among individuals with MBID is a highly relevant topic that has wrongly been neglected by addiction medicine. Thus, while individuals with MBID are a risk group for SUD, they seem to fall between the cracks. The neglect of addiction medicine could lead to ineffective treatment, treatment dropout, and frustrations of both patients and staff members involved. This is not acceptable and certainly not necessary.

This article is meant to address the elephant in the room and wake up the sleeping dogs. That is, this article has addressed the topic that has been ignored by addiction medicine (i.e., SU[D] in individuals with MBID). Given the specific knowledge, skills and resources that are needed to treat SUD in any population, it also urges professionals in addiction medicine to step up and provide treatment adjusted to individuals with MBID. We conclude with some directions for future research and suggestions for policy and practice $[6,23]$. In sum, research within addiction medicine should focus on the detection of MBID among patients being treated in addiction medicine in general and across specific subgroups (e.g., inpatient and outpatient groups, forensic patients), the exploration of specific risk factors for patients with MBID and SUD, the development and implementation of systematic assessment methods of SU(D) among individuals with MBID, and the development and evaluation of prevention and treatment interventions. For example, research has identified several other effective treatment interventions for SUD - in addition to cognitive behavioral therapy and motivational interviewing - that have not yet been studied in patients with MBID, such as assertive community treatment [29] and community reinforcement approach $[30,31]$. In addition, research within addiction medicine should identify barriers to treatment access and propose ways to overcome these barriers and aid referral, including identifying ways to promote cross-system collaboration between ID-care and addiction medicine. In addition, care providers and policy makers should be aware of the possibility of MBID among patients with SUD and pay close attention to high-risk groups to aid early detection. SUD prevention should start at a young age for children with MBID and all treatment interventions should be tailored to the needs of those with MBID. Care providers and policy makers should collaborate with ID-care in the development and implementation of these prevention and intervention programs. A collaborative approach with ID-care will contribute to the success of such a treatment effort and will provide support to professionals working within addiction medicine learning to work with individuals with MBID. Lastly, care providers and policy makers should invest in system integration, interdisciplinary collaboration, training of staff, and reducing treatment barriers to improve the accessibility of care for individuals with MBID. This research, together with the suggestions for policy and practice, are essential for improving the care of individuals with MBID and SUD.

\section{Acknowledgements}

None.

\section{Statement of Ethics}

The authors have no ethical conflicts to disclose.

\section{Disclosure Statement}

The authors have no conflicts of interest to declare. 


\section{Funding Sources}

None.

\section{Author Contributions}

Both authors have played an active role in data collection, preparation and writing of the manuscript.

\section{References}

1 Substance Abuse and Mental Health Services Administration. Results from the 2016 National Survey on Drug Use and Health Substances. Rockville (Maryland): Author; 2017.

2 Degenhardt L, Glantz M, Evans-Lacko S, Sadikova E, Sampson N, Thornicroft G, et al.; World Health Organization's World Mental Health Surveys collaborators. Estimating treatment coverage for people with substance use disorders: an analysis of data from the World Mental Health Surveys. World Psychiatry. 2017 Oct;16(3):299-307.

3 Donovan DM. Assessment of addictive behaviors for relapse prevention. In: Donovan DM, Marlatt GZ, editors. Assessment of addictive behaviors (2nd ed). New York, NY: The Guilford Press; 2005. pp. 1-48.

4 East W. Mental defectiveness and alcohol and drug addiction. Br J of Inebriety. 1932;29(4): $149-68$.

5 American Psychiatric Association. Diagnostic and statistical manual of mental disorders. 5th ed. Washington (DC): Author; 2013.

6 van Duijvenbode N, VanDerNagel JE, Didden R, Engels RC, Buitelaar JK, Kiewik M, et al. Substance use disorders in individuals with mild to borderline intellectual disability: current status and future directions. Res Dev Disabil. 2015 Mar;38:319-28.

7 Carroll Chapman SL, Wu LT. Substance abuse among individuals with intellectual disabilities. Res Dev Disabil. 2012 Jul-Aug;33(4): 1147-56.

8 Didden R, Embregts P, van der Toorn M, Laarhoven N. Substance abuse, coping strategies, adaptive skills and behavioral and emotional problems in clients with mild to borderline intellectual disability admitted to a treatment facility: a pilot study. Res Dev Disabil. 2009 Sep-Oct;30(5):927-32.

9 Nouwens PJ, Lucas R, Smulders NB, Embregts PJ, van Nieuwenhuizen C. Identifying classes of persons with mild intellectual disability or borderline intellectual functioning: a latent class analysis. BMC Psychiatry. 2017 Jul;17(1):257.

10 Turygin NC, Matson JL, Adams HL, Williams LW. Co-occurring disorder clusters in adults with mild and moderate intellectual disability in residential treatment settings. Res Dev Disabil. 2014 Nov;35(11): 3156-61.

11 Van Straaten B, Schrijvers CT, Van der Laan J, Boersma SN, Rodenburg G, Wolf JR, et al.
Intellectual disability among Dutch homeless people: prevalence and related psychosocial problems. PLoS One. 2014 Jan;9(1): e86112.

12 Salavert J, Clarabuch A, Fernández-Gómez MJ, Barrau V, Giráldez MP, Borràs J. Substance use disorders in patients with intellectual disability admitted to psychiatric hospitalisation. J Intellect Disabil Res. 2018 Nov; 62(11):923-30

13 Schijven EP, Engels RC, Kleinjan M, Poelen EA. Evaluating a selective prevention program for substance use and comorbid behavioral problems in adolescents with mild to borderline intellectual disabilities: study protocol of a randomized controlled trial. BMC Psychiatry. 2015 Jul;15(1):167.

14 Hayes S. Hayes Ability Screening Index. Sydney, Australia: Univesity of Sydney; 2000.

15 Wechsler D. WAIS-III administration and scoring manual. San Antonio (Texas): The Psychological Corporation; 1997.

16 Mayfield D, McLeod G, Hall P. The CAGE questionnaire: validation of a new alcoholism screening instrument. Am J Psychiatry. 1974 Oct;131(10):1121-3.

17 Babor TF, Higgins-Biddle JC, Saunders JB, Monteiro MG. AUDIT. The alcohol use disorder identification test: Guidelines for use in primary care. 2nd ed. Geneva: World Health Organisation; 2001.

18 Berman AH, Bergman $\mathrm{H}$, Palmstierna $\mathrm{T}$, Schlyter G. DUDIT. The drug use disorders identification test manual. Stockholm: Karolinska Institutet, Department of Clinical Neuroscience; 2003.

19 VanDerNagel JE, Kiewik M, Van Dijk M, De Jong CA, Didden R. Handleiding SumID-Q, Meetinstrument voor het in kaart brengen van middelengebruik bij mensen met een lichte verstandelijke beperking [Manual of the SumID-Q. An instrument to assess substance use in individuals with a mild intellectual disability] Deventer, The Netherlands: Tactus; 2011.

20 Kerr S, Lawrence M, Darbyshire C, Middleton AR, Fitzsimmons L. Tobacco and alcohol-related interventions for people with mild/moderate intellectual disabilities: a systematic review of the literature. I Intellect Disabil Res. 2013 May;57(5):393-408.

21 McGillicuddy NB. A review of substance use research among those with mental retardation. Ment Retard Dev Disabil Res Rev. 2006; 12(1):41-7.
22 Frielink N, Embregts P. Modification of motivational interviewing for use with people with mild intellectual disability and challenging behaviour. J Intellect Dev Disabil. 2013 Dec;38(4):279-91.

23 van Duijvenbode N. The potential usefulness of implicit measures to assess and treat problematic substance use in individuals with mild to borderline intellectual disability: setting a research agenda. Adv Neurodev Disorders. 2017;1(2):107-9.

24 van Duijvenbode N, Didden R, Korzilius HP, Engels RC. The usefulness of implicit measures for the screening, assessment and treatment of problematic alcohol use in individuals with mild to borderline intellectual disability. Adv Neurodev Disorders. 2017;1(1): 42-51.

25 Pezzoni V, Kouimtsidis C. Screening for alcohol misuse within people attending a psychiatric intellectual disability community service. J Intellect Disabil Res. 2015 Apr;59(4): 353-9.

26 VanDerNagel JE, Kiewik M, Buitelaar JK, De Jong CA. Staff perspectives of substance use and misuse among adults with intellectual disabilities enrolled in Dutch disability services. J Policy Pract Intell Disabil. 2011;8(3): 143-9.

27 Barrett N, Paschos D. Alcohol-related problems in adolescents and adults with intellectual disabilities. Curr Opin Psychiatry. 2006 Sep;19(5):481-5.

28 Slayter E. Adults with dual eligibility for Medicaid and Medicare: access to substance abuse treatment. J Soc Work Disabil Rehabil. 2011; 10(2):67-81.

29 Penzenstadler L, Soares C, Anci E, Molodynski A, Khazaal Y. Effect of assertive community treatment for patients with substance use disorder: A systematic review. Eur Addict Res. 2019;25(2):56-67.

30 Roozen HG, Boulogne JJ, van Tulder MW, van den Brink W, De Jong CA, Kerkhof AJ. A systematic review of the effectiveness of the community reinforcement approach in alcohol, cocaine and opioid addiction. Drug Alcohol Depend. 2004 Apr;74(1):1-13.

31 Søgaard Nielsen A, Nielsen B, Andersen K, Roessler KK, Bühringer G, Bogenschutz M, et al.; RESCueH Research Group. The RES$\mathrm{CueH}$ programme: Testing new non-pharmacologic interventions for alcohol use disorders: Rationale and methods. Eur Addict Res. 2016;22(6):306-17. 